\title{
A Summary on Internal Government and Research Difficulties of the Private Higher Education in 2017
}

\author{
Zhang Jian \\ Qifang Education Research Institute, Xi’an International University, Xi’an Shaanxi, 710077
}

Keywords: private higher education; feature; internal government; research difficulties

\begin{abstract}
In 2017, the private higher education of China has had some characteristics, including the declining profit orientation of the organizer; the transformation from the developmental model that focuses on the hard power of "striving for living" into focusing on the soft power of "living well and living for a long time"; the constantly improved registration of juridical persons and the system of property rights; increased government support; the guaranteed lawful right and interests of teachers and students, etc. Many scholars have studied the internal government of private colleges and universities, but at the same time, there are still some problems, such as the researchers are fewer, research teams are weak, and the ways, directions and contents of the research are not in accord with the reality of the development of private education, etc. These problems could be solved by means of constructing think tank and platform, optimizing the mechanism, increasing investment, and equally emphasizing internal and external aspects, etc.
\end{abstract}

In recent years, some scholars have carried out extensive discussions on aspects, including the nature of property rights in the development of private education, government support, corporate government, striving for first class, personnel selection, risk prevention, coordinated development, improving quality, running schools by joint venture, future thinking, summarizing the history, and learning from foreign advanced school experience, etc.

\section{Developmental Characteristic of Private Higher Education}

As the reform and development of education entering a new stage, private education in China has shown the following characteristics: the profit orientation of the organizer tends to fade and they start having great ambitions of education; the traditional logic of running a school is difficult to continue, and it has become a trend to follow the inherent laws of education; the developmental model that focuses on the hard power of "striving for living" is transforming into focusing on the soft power of "living well and living for a long time"; the registration of juridical persons and the system of property rights are constantly improved but some deep problems need to be solved; government support has been increased but the ways of raising funds need to be increased; the lawful right and interests of teachers and students are guaranteed but the guarantee mechanism need to be improved; awareness of internal standard has enhanced and the construction of corporate government institution has speed up; the autonomy of running schools has expanded, and the some time, decentralization, management, services need to be upgraded synchronously ${ }^{[1]}$. Therefore, on this basis, the scholars have constructed the theoretical space and the realistic picture of the discourse right of the private colleges ---- "Localization" of discourse right is a normal way of expressing the opinions to others and receive the advices from others of the private colleges and universities ${ }^{[2]}$. Looking forward to the future, the experts believe that the higher education should be oriented toward people, the future and the world. In order to be in the leading position of the thought, the university must have independent spirit and free thought, must cultivate the student's critical spirit and question spirit, must evoke the student's potential abilities of active studying and practice from the perspective of subjective initiative and improve the students' ability to solve complex problems ${ }^{[3]}$. 


\section{Current Research Situation of Internal Management of Private Colleges and Universities}

While the state and society are vigorously supporting the development of private colleges and universities, the construction of private colleges and universities is particularly important. While talking about the external government strategy of private colleges and universities, the improvement of internal government structure is an inevitable topic in the construction of private colleges and universities. On the property of investment in running private colleges and universities in China, Wang Hua, Wang Yitao and Wang Deqing have probed into the evolution and return of the organizers' rights of the private colleges and universities from the legal point of view. In their opinion, only by means of accurately defining the rights of the organizers of private colleges and universities can the relationship between the organizers and the schools be clarified well; only by this way can the schools ensure and standardize the organizers' behavior and promote the healthy development of private colleges and universities. Therefore, it is necessary to promote the construction of laws and regulations under the framework of classified management, clarify and protect the rights of the organizers, at the same time, strengthen the administrative supervision of the government, strengthen the supervision by public opinion and social intermediary organizations, and balance the power within the schools so as to restrict and supervise the actual right of the schools, and to achieve the unification of the actual right, the legal right and the due right ${ }^{[4]}$. On the construction of the board of trustees of private colleges and universities, board chairman Hu Dabai of Huanghe Science and Technology University believes that the construction of the board of trustees is of great importance to the survival and development of private colleges and universities. If people who study the problems of private education in China can not break through the research paradigm of being crazy about foreign things and obsequious to foreigners, they cannot put forward a real plan to solve the problem of private education in China. Therefore, we can only build our own cultural self-confidence, theoretical self-confidence, institutional confidence, road confidence; at the some time, we must follow the reality of China and the scientific concept of development, scientifically design the board of trustees system of private colleges with Chinese characteristics, so as to make private colleges and universities in China can really take the road of rapid, healthy and sustainable development ${ }^{[5]}$.

The president, as the key person who leading the development of the private colleges and universities, the selection and appointment of the president of the private colleges and universities are crucial to the current and future development of private colleges and universities so that the future is very important. Chen Hong, Yuan Bentao, by the investigation of the background of the current presidents of 93 private colleges and universities, find that there are two ways of appointing the presidents of private colleges and universities in China at present, i.e., the internal appointment and external recruitment. In their research, we can find that the average age of external recruitment presidents is 63.24 years old, their average term of service is 3.8 years; the average age of internal appointment presidents is 52.67 years old, their average term of service is 13.8 years; most of the external recruitment presidents are the former presidents, vice-presidents or secretaries of public colleges and universities, most of them have the title of professor and have a high academic reputation, but the internal presidents are mainly good at teaching ${ }^{[6]}$. Qiu Kunshu, Wang Yitao, Shi Meng, by the investigation of the background of 238 presidents of the private colleges and universities, find that there are three main ways of appointing the presidents of private colleges and universities in China, i.e., the organizers undertake the posts directly or their family members undertake the posts, the external appointment and the internal cultivation, and most of the external appointment presidents are the retired leaders of the public colleges and universities. When the idea of an external appointment president conflicts with the idea of the organizer, the external appointment president is often forced to leave the school while the internal cultivation president of the school often has higher loyalty. So, according to the investigation, they appeal the private colleges and universities to improve the appointment systems of the schools, and it is necessary to give more innovative space to the presidents of private colleges and universities on the basis of the characteristics of schools and the premise of the schools' long-term development ${ }^{[7]}$. With regard to the operation of the board of trustees and the selection and appointment of the president, Zhang 
Leisheng and $\mathrm{Wu}$ Dandan draw lessons from the establishment and operation of the board of trustees of Harvard University and Yale University, and put forward the following strategies for perfecting the internal government mechanism of the private colleges and universities in China: first of all, the board of trustees and the trustee council shall be established in strict accordance with the Higher Education Law and the situation of the university itself; second, the government and the relevant education authorities must clarify their rights and duties; third, the members of the board of trustees and the trustee council must have the feature of open and representativeness; fourth, clarifying the duty of the board of trustees and the trustee council, and strictly prohibit they interfering in the normal operation of school affairs; at last, the board of trustees and the trustee council must keep a good relationship with the Party committee, the school committee, the labor union and the other administrative organizations, at the same time, they should make a proper position about themselves and establish an effective self supervision mechanism ${ }^{[8]}$. In Tao Xiping's Opinion, no matter what kind of construction of mechanism system, as an important part of the education system of China, the private education must take the best of its flexible running mechanism, promote the supply-side reform of education by means of improving the quality of running a school. In order to achieve this objective, the leaders of the private colleges and universities must have "four eyes", i.e., one eye focuses on the circumstances; one eye focuses on the market; one eye focuses on the relevant policy; and one eye focuses on themselves, only by this way can they lead the healthy development of the private colleges and universities ${ }^{[9]}$. In view of the current situation of private colleges and universities in China, Wang Zuoshu, the director of the Private Education Association of China, called for the reform of private colleges and universities to follow the principles of "three ideas, two rules and the principle of running a school in 24 characters"----the private colleges and universities should not only have "the ideas of educationist, the ideas of strategist, the ideas of entrepreneur", but also follow "the rule of education and the rule of market economy", at the some time, the private schools should run schools in accord with the principle of "following the rule of running schools, carrying out the educational policy, optimizing the way of education, chase for the quality of education", so as to cultivate more and better talents for the country and make greater contributions to the development of society ${ }^{[10]}$.

\section{Difficulties in the Study of Private Higher Education}

There are still many areas need to be improved in the research of private higher education, the problems are mainly reflected in the following aspects:

First, the number of researchers is small, the research team is weak, and the research problems are scattered.

According to the National Education Development Statistics Bulletin 2016, there were 742 private colleges and universities (including 266 independent colleges) in China by the end of 2016. However, apart from the establishment of specialized research institutions in Beijing, Shanghai, Guangdong, Zhejiang and other provinces (cities), most of the research of private education in most provinces (cities) mainly attach to public colleges and universities. Moreover, there is a peculiar phenomenon that the more developed areas of private education are weak in the quantity of the Institutions and researchers that research private education. Except for Xi'an International University, Zhejiang Shuren University, Beijing City University, Huanghe Science and Technology University and so on, most of the private universities do not have specialized institutions for researching private education. Even if a specialized institute is established in the colleges and universities, the staff of the institute is mainly the retired teachers of public institutions or other related units, and a lot of the researchers of these institutes are only honorary researchers, and the full-time researchers is very few. As a kind of platform for displaying research results, although all private universities have journals and other similar publications, but except for the Journal of Zhejiang Shuren University, Journal of Huanghe Science and Technology University, Journal of Beijing City University and Periodical of Hubei Correspondence University, which have their Public publications, the rest private colleges and universities' journals all in-house literatures, which have a very limited role in motivating the researchers enthusiasms. Limited by institutes and 
personnel, the research direction of private education is also very scattered, there is no long-term developmental planning of the private higher education, and it is lack of the discourse right on the issue of private education.

Because of the lack of mature experience that can be used for reference, the phenomenon of "be subservient to foreigners" in the study of the issue of private education is everywhere. There are many researchers in public colleges and universities who resent the rigid system of public universities or yearn for academic freedom in western developed countries. In their research, there is always a kind of "Western adoration" that does not fully take into account the reality of China's national conditions, and that emphasizes on macro interpretation of policy but lacks of application orientation and awareness of problems. At the some time, it lacks of research on strategy and college, so that the research findings often do not respond to the case. For example, the revised Private Education Promotion Law, in which classified management is the highlight of the new law, was formally implemented on September 1st, 2017, but up to now, the theoretical scheme with strong practicability has not been formed. For example, the party building is another important bright spot of the new law, but the research on the party construction in the private colleges and universities is still relatively few; the supervision and evaluation mechanism of the intermediary organizations has not really been established; on how the government support the private higher education in aspect of finance, on how to supervise the colleges and universities and so on, there is no any meaningful articles that the writer have read. There are a lot of articles that emphasize qualitative analysis more but neglect quantitative research, that are more emphasis on theory but less on practice, and that are lack of systematization and strong practicability. The reason for the above problems dues to the fact that private education research is limited by factors such as personal professional background, academic vision, knowledge experience, and the atmosphere of research in private colleges and universities is not very strong, so that it is impossible to tackle key problems by the joint effort.

Base on the above analysis, with regard to the research of private education, we must combine the national conditions and culture of China, base ourselves on the reality of each private college or university, strengthen the construction of the research team of private education, and recruit the talents who are from different disciplines and different majors, such as pedagogy, economics, management, jurisprudence, mathematics and so on. Meanwhile, we must get rid of the stereotype of idea in traditional theories, avoid the stereotype of utilitarian research, it is necessary to promote deep cooperation among different social forces such as academic circle, legal profession, economic entities, experts and private education practitioners by means of building think tanks, building platforms, optimizing mechanisms, increasing investment, paying equal attention to both inside and outside, and give consideration to all aspects, etc. We must insist on problem-orientation, highlight applied research, make overall plans and take all factors into consideration, and research the actual problems of private colleges and universities, so as to promote a number of significant research results that could provide some references for the government and for the development of the private colleges and universities, so as to provide intellectual support and ideological contributions to the development of private education, so as to promote the sustained, healthy and rapid development of private education, and so as to build a brilliant future of private education in China.

\section{Acknowledgment}

Scientific Research Program Funded by Shaanxi, Provincial Education Department (Program No. 13JZ076)

\section{References}

[1] Zhou Haitao, Yan Liwen. Developmental Trend and the Deliberation on the Development of Private Education in China[M]. Huang Teng, Research on Private Higher Education of China 2017. Shanghai: East China Normal University Press, 2017. 
[2] Yang Xiaopei, Song Lijuan. The Discourse Right of Private Colleges: Theory Space and Reality Picture [M]. Huang Teng, Research on Private Higher Education of China 2017. Shanghai: East China Normal University Press, 2017.

[3] Li Peigen. Expectation and Challenge: Higher Education Should Face the Future[M]. Huang Teng, Research on Private Higher Education of China 2017. Shanghai: East China Normal University Press, 2017.

[4] Wang Hua, Wang Yitao, Wang Deqing. The Evolution and Return of the Rights of the Organizers of Private Colleges and Universities[M]. Huang Teng, Research on Private Higher Education of China 2017. Shanghai: East China Normal University Press, 2017.

[5] Hu Dabai. Deliberation on the Construction of the Board of Trustees of the Private Colleges and Universities[M]. Huang Teng, Research on Private Higher Education of China 2017. Shanghai: East China Normal University Press, 2017.

[6] Chen Hong, Yan Bentao. Deliberation on the current situation and selection of the Presidents of Private Colleges and Universities in China[M]. Huang Teng, Research on Private Higher Education of China 2017. Shanghai: East China Normal University Press, 2017.

[7] Qiu Kunshu, Wang Yitao, Shi Meng. The Characteristics of the Presidents of the Private Colleges and Universities in China and the Inspiration of the Policies[M]. Huang Teng, Research on Private Higher Education of China 2017. Shanghai: East China Normal University Press, 2017.

[8] Zhang Leisheng, Wu Dandan. A Comparative Study on the Operating Mechanism of the Corporate Council of the Top Private Universities in the World[M]. Huang Teng, Research on Private Higher Education of China 2017. Shanghai: East China Normal University Press, 2017.

[9] Tao Xiping. Improving the Quality of Private Education and Promoting the Supply Side Structural Reform of Education[M]. Huang Teng, Research on Private Higher Education of China 2017. Shanghai: East China Normal University Press, 2017.

[10] Wang Zuoshu. Deliberation on the Present Situation and the Development of Private Education in China[M]. Huang Teng, Research on Private Higher Education of China 2017. Shanghai: East China Normal University Press, 2017.

\footnotetext{
About the Author:

Zhang Jian(1986----), comes from Xi'an, Shaanxi Province

Title: Assistant Researcher of Qifang Education Research Institute, Xi'an International University

Research Direction: Private Higher Education
} 